logos_i_ethos_2016_(43)_numer_specjalny_2, s.149-164

DOI: http://dx.doi.org/10.15633/lie.1966

Елена Михайлова

\title{
Петр Чаадаев и Павел Милюков: на грани философии и политики
}

Российские интеллектуалы в своем обращении к философии истории двигались разными путями: одни подходили к вопросам о сущности исторического развития с особыми практиче-

Елена Михайлова - доктор философских наук, профессор Тверского государственного технического университета. E-mail: mihaylova_helen@mail.ru. Научные интересы: философия истории, русская философия, философия позитивизма. ским запросами, другие - задавались ими в надежде обеспечить себя философско-теоретической базой ${ }^{1}$. В обоих случаях исторический материал являл русским мыслителям особую почву для формирования общего мировоззрения, для понимания и измерения действительной реальности.

Перекрестная референция судеб Чаадаева и Милюкова интересна в двух контекстах. Во-первых, как показывают сами авторы и их биографы, в своей жизни оба мыслителя пытались сделать выбор: остаться потенциальным политиком/ученым или, наоборот, стать философом истории/политиком. Во-вторых, вызывает интерес профессиональное мнение Милюкова относительно историософских воззрений Чаадаева. Так сложилось, что Милюков оказался первым профессиональным критиком философии истории Чаадаева. В работе Главные течения русской исторической мысли им показано, что творчество Чаадаева стало импульсом для размышлений

1 См. Н. А. Бердяев, Философская истина и интеллигентская правда, в: Вехи. Из глубины, ред. А. А. Яковлев, Москва 2010, с. 49-50; П. Н. Милюков, Воспоминания, Москва 1991, c. 12. 
отечественных философов самых разных направлений ${ }^{2}$. В другой работе Интеллигениия и историческая традиция он характеризует интеллигенцию, переживающую за судьбу России, в частности, авторов сборника «Вехи», сквозь призму чаадаевского духа: «Они читатели Чаадаева» ${ }^{3}$. Заметим, не «почитатели», а «читатели». Тем самым Милюков подчеркивает значимость Чаадаева как интеллектуального «возмутителя спокойствия» не только современного ему московского общества, но и последующих поколений российской интеллигенции.

Согласно герменевтическому посылу, носитель действенно-исторического сознания всегда событийно связан с ситуацией, в которой он обнаруживает себя в настоящем. Критическое осмысление прошлого своей страны заставляет мыслителя балансировать на грани историко-философской рефлексии и политики ${ }^{4}$. В поисках ответа на вопросы «кто мы?», «чем мы отличаемся от других?» и «что между нами общего?», - русский мыслитель, живущий в эпоху перемен, полную надежд и разочарований, переходит грань между философией и политикой с разной векторной направленностью. Чаадаев «ушел» из сферы публичной политики, погрузившись в историко-философскую рефлексию. Милюков, наоборот, благодаря философско-историческим изысканиям, обратился к сфере политики в надежде реализовать свои либеральные убеждения. Биографии Чаадаева и Милюкова, их взгляды, творчество и способ поэтапного и потенциально незавершенного восхождения опыта миропонимания - все это имеет очевидные различия. Однако, в духе сегодняшнего времени, справедливо искать не различия, а сходства. Стратегии критического осмысления

2 См. Р. В. Кондуров, Историософия П. Я. Чаадаева как проблема русской культуpы: историко-философский аспект. Автореферат диссетрации, Краснодар 2003.

3 П. Н. Милюков, Интеллигенция и историческая традиция, в: Анти-Вехи. Интеллигенция в России. «Вехи» как знамение времени, ред. В. В. Сапов, Москва 2007, с. 116.

4 См. Культура и политика: Сборник научных трудов, ред. Б. Л. Губман, Э. Матыня, Тверь 2004; Е. Е. Михайлова, Особенности философии истории русского позитивизма, «Вече» 27 (2015) 2, с. 48-57. 
истории и культуры, предложенные обоими мыслителями в разных пространственно-временных рамках, важны как способ символического выражения их патриотических переживаний в перспективе поиска национальной и культурной идентичности России.

Если начинать разговор с отличий, то они, на первый взгляд, коренятся во многом: в происхождении, в убеждениях, в идейно-теоретических корнях, сформировавших мировоззренческую позицию. Жизнь каждого мыслителя складывалась в чертах, типичных для его круга и поколения. Мировоззрение Чаадаева соответствовало канонам высшего дворянского происхождения и воспитания. Он был племянником князей Щербатовых, унаследовавших крупное состояние, и внуком русского историка Щербатова по матери. Милюков, напротив, воспитывался в семье с небольшим достатком. Его отец никакими наследственными средствами не обладал, имея скромный заработок служащего (преподаватель, инспектор художественных училищ, городской архитектор, оценщик в банке), а мать владела небольшим поместьем в Ярославской губернии.

Убеждения избранных для сравнения мыслителей отличаются друг от друга, как и их происхождение, и воспитание. Чаадаев, как известно, рефлексировал в религиозно-мистических категориях, Милюков разделял научные интересы. Чаадаев не возлагал надежд на конституцию, а желал восстановления «старинной дисциплины, общественной и нравственной» ${ }^{5}$. Милюков, напротив, был вовлечен в дискуссию о перспективах развития страны и в политические события на рубеже XIX-XX веков, возлагал надежды на реализацию конституции как политического гаранта модернизации России.

Принципиально отличались и идейно-теоретические корни, взрастившие обоих мыслителей. Сильно разнятся авторы, которые сформировали мировоззренческую позицию каждого. Для Чаадаева такими стали религиозные философы Ю. Штиллинг, Ж. де-Местр, Ж. Боссюэт, Л. Бональд и, конечно, Ф. Шеллинг. Их

5 П. Н. Милюков, Главные течения русской исторической мысли, т. 1, Москва 1898, c. 375 . 
идеи сводились к тому, что христианство, в частности, католичество как его деятельно-нравственная форма, олицетворяет прогресс; все, в том числе и свобода человеческой воли, предустановлено Провидением. Мировоззрение Милюкова формировалось под влиянием концепций Г. Спенсера, Ф. Гизо, П. Г. Виноградова, В. О. Ключевского. В числе главных идей этих теоретиков было то, что история - это не хронологический пересказ фактов и событий, а процесс многообразного сочетания культурных и социальных форм, пронизанный гуманистическим смыслом.

Несмотря на мировоззренческие и теоретико-методологические отличия взглядов Чаадаева и Милюкова, их биографии и мыслительные конструкции многое объединяет: специфика семейного воспитания, университетское образование, лингвистические пристрастия и, что наиболее важно, попытки построить самобытные философско-исторические модели в жизненном пространстве, полном перемен и бурных политических событий.

\section{Самовоспитание}

В жизни каждого мыслителя отсутствовала семейная гармония, в широком смысле этого слова, что во многом стимулировало с ранних лет «свободу самовоспитания». Проявлялось это по-разному: Чаадаев воспитывался без родителей, но в теплом кругу родных, Милюков - с родителями, но в постоянной оппозиции родительским заботам. В итоге Чаадаев был общим любимцем и рос «своевольным ребенком» ${ }^{6}$. Биографы и исследователи единодушно признают его "раннюю самостоятельность» и напрямую связывают факт сиротства со свойственным ему обостренным чувством независимости ${ }^{7}$. Милюков же, по его собственному признанию, считал, что «сам всем себе обязан» ${ }^{8}$.

6 М. Гершензон, П. Я. Чаадаев. Жизнь и мылиление, Санкт-Петербург 1908, с. 5.

7 А. И. Кирпичников, П. Я. Чаадаев, «Русская мысль» 17 (1896) 4, с. 145.

8 П. Н. Милюков, Воспоминания, Москва 1991, с. 37-38. 


\section{Университетский круг}

Чаадаева обучали на дому лучшие профессора Московского университета - А. Ф. Мерзляков (словесность), И. Ф. Буле (философия), Ф. Г. Баузе (право), Х.-А. Шлецер-сын (юриспруденция) ${ }^{9}$. Вкусив плоды либерального университетского духа, Чаадаев воспринял социальное настроение русского передового общества ${ }^{10}$. Людям его поколения, его друзьям-декабристам были свойственны высокие нравственные, общественные и гражданские убеждения. Через полстолетия такое же обостренное чувство ответственности за историческую судьбу своей страны будет испытывать и Милюков. Выходец из мелкопоместной дворянской среды, он учился в Московском университете пореформенной эпохи, поэтому воспринял мировоззренческие представления, свойственные интеллигенции, ратующей за демократическую модернизацию российского государства и общества. Годы университетской учебы Милюкова пришлись на смену поколений преподавателей: от старших В. И. Герье и С. М. Соловьева до молодых П. Г. Виноградова и В. О. Ключевского, которые приобрели репутацию представителей нового взгляда на историю и методы ее познания. В своих Воспоминаниях Милюков прямо именует последних «настоящими светилами учености и таланта» ${ }^{11}$. Свободолюбивая университетская атмосфера давала возможность студентам всех поколений учиться критически мыслить и свободно высказываться, усиливала тягу к историко-философской рефлексии. Выпускник Московского университета, историк А. А. Кизеветтер в своей статье, посвященной 150-летию своей «alma mater» наделяет ее пышным эпитетом - «наша духовная отчизна» ${ }^{12}$. Он подчеркивает значимость академической свободы для интеллектуального и нравственного обогащения всех поколений русского общества. Немаловажным

\footnotetext{
9 А. И. Кирпичников, П. Я. Чаадаев, ор. cit., с. 148.

10 М. Гершензон, П. Я. Чаадаев. Жизнь и мылиление, ор. cit., с. 61.

11 П. Н. Милюков, Воспоминания, ор. cit., с. 71.

12 А. А. Кизеветтер, Московский университет и его традиции, «Русская мысль»
} 26 (1905) 1, c. 12. 
является и то, что университет, в самые разные эпохи давал своим студентам серьезную лингвистическую подготовку: Чаадаев осваивал университетскую программу словесного отделения, Милюков обучался на историко-филологическом факультете. Во многом именно этим объясняется глубокий интерес будущих мыслителей к «слову», к «высказыванию» как средству выражения своей жизненной позиции. Оба имели обширную домашнюю библиотеку.

\section{Умственный облик}

Мировоззренческие установки Чаадаева и Милюкова складывались под впечатлением грандиозных событий, потрясавших в разное время Европу и Россию. И это понятно: всплеск интереса к постижению вопросов социокультурного развития всегда вызван особой жизненной ситуацией. Для Чаадаева такими событиями стали Великая французская буржуазная революция, заграничные походы в составе русской армии 1813-1815 годов, личная заграничная поездка 1821-1825 годов. На Милюкова оказали воздействие такие события, как всплеск освободительного движения на Балканах на рубеже веков, революция 1905 года, становление российского парламентаризма, Первая мировая война, падение самодержавия, а также личные заграничные поездки.

Таких столь разных мыслителей, как Чаадаев и Милюков, объединяет схожая гражданская и исследовательская позиция. Каждый из них в свое время поставил вопрос о национальных особенностях развития России и ее исторической роли во всемирно-историческом процессе. Для обоих мыслителей знание истории - это, прежде всего, ответ на вызов современности. Оба воспринимали исторический материал как возможность «спрашивать», чтобы получить ответы на актуальные вопросы настоящего. Чаадаев - через «социальный мистицизм» или «рациональный мистицизм», по выражению ис-

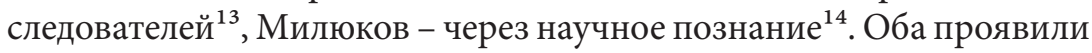

13 М. Гершензон, П. Я. Чаадаев. Жизнь и мылиление, ор. cit., с. 64.

14 П. Н. Милюков, Воспоминания, ор. cit., с. 55. 
себя носителями интеллектуального и нравственного духа, яркими индивидуальностями. Оба рассматривали исторический материал не только как важный познавательный ресурс, но и как символический способ выражения ответственности за историческую судьбу России. История их интересовала как ресурс для преобразования настоящего. «Спросим снова историю: именно она объясняет народы» - рефреном звучат слова Чаадаева ${ }^{15}$.

Анализируя историософские воззрения Чаадаева, Милюков критикует его «полное и категорическое отрицание культурно-национальной русской традиции» ${ }^{16}$. Однако он склонен считать это нарочитой демонстрацией пессимистического настроения, которое испытывал Чаадаев в годы долгого уединения. В рассуждениях Чаадаева о прошлом России как о «белом листе бумаги» Милюков улавливает метафору, под которой скрывается не отрицание культурных начал русской истории и не отсутствие патриотических чувств автора, а, скорее, его эмоционально окрашенные болезненные переживания по поводу отсутствия «исторического сознания» и «исторических воспоминаний». Милюков считает, что такое «решительное и безусловное отрицание всего русского прошлого во имя русского будущего» связано с пониманием, что без христианства нет прошлого, нет цельной и осмысленной истории ${ }^{17}$. Милюков справедливо парирует, что слишком много было пережито русским обществом и русским народом, чтобы можно было не признавать плоды прожитого. Однако вслед за Чаадаевым он признает, что русская жизнь в ее прошлом была мало проникнута началами веры, но прошлого уже не вернуть, надо думать о настоящем.

У нас есть прошлое, заслуживающее уважения и национального культа. Русская культурная традиция была. Она была уже тогда, когда три четверти

15 П. Я. Чаадаев, Философические письма, в: П. Я. Чаадаев, Полное собрание сочинений и избраннье письма, т. 1, Москва 1991, с. 331.

16 П. Н. Милюков, Интеллигениия и историческая традиция, ор. cit., с. 144.

17 См. П. Н. Милюков, Главнье течения русской исторической мысли, т. 1, op. cit., c. 374,380 . 
века назад ее фанатически отрицал Чаадаев. Теперь эта традиция гораздо длиннее и богаче. Она пополнилась списком великих имен, которые дают нам уже теперь некоторое право на тот вид «мессианства», какого может добиваться культурная нация

- пишет Милюков в 1909 году ${ }^{18}$.

Любопытно отметить, что критика чаадаевского отрицания традиции не мешает Милюкову причислить его к обозначенному «списку великих имен». И помещает Чаадаева, с его посылом к культурному мессианству, в один ряд с такими личностями, как Юрий Крижанич, славянофилы, Владимир Соловьев, т.е. с теми, кто пытался, хотя и безуспешно, преодолеть узко национальные границы народного сознания в поисках вселенской веры ${ }^{19}$. Гершензон причисляет Чаадаева к людям, символизирующим патриотический и национальный дух страны. Вот каким видится Чаадаев 30-х годов Гершензону: «Тогда, угрюмый отшельник, выброшенный из жизни, он являлся судьею-обвинителем своей родины, - а судить можно только прошлое и настоящее: теперь, упокоившись и вернувшись в действительность, он почувствовал себя гражданином, и его мысль направилась вперед, в будущее» ${ }^{20}$.

Милюков справедливо отмечает тесную связь философии Чаадаева и Шеллинга. Он считает, что в шеллингианской философии истории были положения, которые Чаадаев легко мог воспринять, и, наоборот, не воспринять. Чаадаев, по мнению Милюкова, говорит «да» всемирно-исторической перспективе и «нет» - национальному самолюбию21. Вслед за Шеллингом Чаадаев воспринимает народы как национальные организмы, представляющие свою особую идею; их развитие осуществляется по воле Провидения в соответствии

18 П. Н. Милюков, Интеллигенция и историческая традиция, ор. cit., с. 157.

19 См. П. Н. Милюков, Интеллигениия и историческая традиция, ор. cit., с. 146-147.

20 М. Гершензон, П. Я. Чаадаев. Жизнь и мьишление, ор. cit., с. 148.

21 П. Н. Милюков, Главные течения русской исторической мысли, т. 1, op. cit., с. 386. 
со сменой вызревания новых идей. Однако, Чаадаев привносит свои ноты в понимание национального прошлого и всемирно-исторического будущего России, рассуждая о том, что надо жить своей жизнью с самого начала, а не «чужой» - «с середины». В его понимании, каждый народ должен сам найти внутреннюю связь между прошедшим и настоящим. В замыслах Чаадаева, каждый народ по-своему проходит стадии роста и зрелости. Период «юности» каждого народа - это время выработки самых ярких воспоминаний и плодотворных идей, «пора великих побуждений» ${ }^{22}$. Чаадаев считает, что этот период обернулся для России исключительными геополитическими трудностями - «дикое варварство», «грубое суеверие», «иноземное владычество». Двигаясь в русле рассуждений русского историка Н. М. Карамзина, он считает, что дух лицемерного и жестокого монголо-татарского владычества исторически был унаследован московскими князьями, проникнув впоследствии в менталитет национальной власти.

Относительно важности исторических фактов Чаадаев высказывает, конечно, недальновидные суждения. Он считает, что «все сырье истории уже исчерпано», что выявлены все традиции народов, что никакое критическое осмысление новых фактов не приведет к новым открытиям. Однако продуктивным моментом этих рассуждений является мысль о том, что признаки исторической достоверности следует искать не столько в «хронике» событий, сколько и в их нравственной оценке. Именно поэтому история, на его взгляд, может занять свое место в общей системе философии не как наука о собирании и классификации фактов, а как наука, осмысляющая их сквозь призму нравственно наполненного разума ${ }^{23}$. В чем видится Чаадаеву потенциальная сила такой рефлексии? Благодаря ей появляется возможность поставить под сомнение «величие» неких веков, приписываемое когда-то традицией; подвергнуть фальсификации сложившуюся репутацию и славу определенных исторических

22 П. Я. Чаадаев, Философические письма, ор. cit., с. 324.

23 П. Я. Чаадаев, Философические письма, ор. сіt., с. 395. 
событий и исторических личностей. Чаадаев призывает избавиться от «лживых образов», которые «загромождают память людей» и не дают вынести уроки прошлого для позитивного осмысления настоящего и будущего ${ }^{24}$. Самый важный урок философии истории, по Чаадаеву, заключается в ее возможности свести воедино мыслительную конструкцию о прошлом и настоящем как «всемирную жизнь сознательного существа», способную раскрыть «загадку человечества» ${ }^{25}$.

Мечты о космополитическом будущем Чаадаев считает не более, чем химерой. Сначала, на его взгляд, надо заняться выработкой «домашней нравственности» самого народа. Для этого надо сделать довольно сложные в ценностно-практическом смысле шаги: научиться «знать и оценивать самих себя», «знать свои пороки и добродетели», «раскаиваться в своих ошибках и преступлениях», «исправлять совершенное зло», «упорствовать в добре». Такие ориентиры важны для выработки совершенствования каждого народа и отдельной личности. И народ в целом, и каждый человек в отдельности для выполнения своего предназначения в мире должен изучать свои культурно-исторические корни, чтобы «найти свое будущее в своем прошлом». В таком ракурсе историческая критика прошлого из предмета пустого любопытства превращается в средство «высочайшего судилища» ${ }^{26}$.

Исследователи творчества Чаадаева солидаризируются в том, что его «традиционно-христианская», в терминологии Милюкова ${ }^{27}$, историософская концепция представляет собой содержательную метафизическую систему, пронизанную идеей абсолютной значимости христианства для развития человечества. Тексты Чаадаева, пронизанные христианскими убеждениями автора, настойчиво взывают к философскому осмыслению отечественной истории.

24 П. Я. Чаадаев, Философические письма, ор. cit., с. 399.

25 П. Я. Чаадаев, Философические письма, ор. cit., с. 400.

26 П. Я. Чаадаев, Философические письма, ор. сіt., с. 398.

27 П. Н. Милюков, Главные течения русской исторической мысли, т. 1, ор. сit., с. 378. 
В этом контексте можно отметить, что чаадаевская версия философии истории видится приемлемой и для человека, живущего в пространстве религиозной веры и за ее пределами. Во многом благодаря Чаадаеву, вопрос о том, чему учит история, находит свой ответ в формуле: прошлое «просит» настоящее. Эта мысль сегодня неоспорима, она укоренилась в сознании исследователей ${ }^{28}$.

Схожие историко-философские убеждения проявит через полстолетия и Милюков. Продуктивным моментом построений его известных Очерков по истории русской культуры (1896-1909 гг.) является идея многофакторной эволюции народов как культурных и общественных образований. Как свидетельствуют биографы, Чаадаев писал письма о философии истории в тот момент своей жизни, когда он был в тяжелом душевном настроении, «в годы уединенного сосредоточения и творчества» ${ }^{29}$. Милюков, наоборот, работал над своими Очерками, как правило, с деятельным настроем. Его жизненный путь, насыщенный ссылками, эмиграцией, депутатской и министерской деятельностью, оказался в целом пронизанным позитивными устремлениями: ученый жаждал реализовать свои историко-философские взгляды в реальной политической деятельности. За критическую оценку власти Милюков отбывал ссылку в Рязани, где и начал писать задуманные им Очерки. После дальнейшей череды событий, связанных с противостоянием самодержавному режиму, ему пришлось уехать в вынужденную эмиграцию. И это время он потратил достаточно продуктивно: работал в библиотеке Британского музея над продолжением Очерков, читал лекции по русской истории в США и Болгарии.

Будучи учеником Ключевского, Милюков воспринял и творчески развил идеи известного историка. Как и Ключевский, он представлял историю как процесс трансформации многообразных сочетаний культурных и социальных форм. Ключевский, оценивая предмет истории, говорил, что прошедшее есть «урок»:

28 П. С. Гуревич, Чему учит история?, «Вестник аналитики» 56 (2014) 2, с. 100.

29 М. Гершензон, П. Я. Чаадаев. Жизнь и мылиление, ор. cit., с. 104-105. 
Изучая дедов, узнаем внуков, изучая предков, узнаем самих себя. Без знания истории мы должны признать себя случайностями, не знающими, как и зачем мы пришли в этот мир, как и для чего в нем живем, как и к чему должны стремиться, механическими куклами, которые не родятся, а делаются, не умирают по законам природы и жизни, а ломаются по чьему-то детскому капризу ${ }^{30}$.

По признанию самого Милюкова, русская история для университетской молодежи пореформенной поры была просто грудой фактов.

В. О. Ключевский построил для нас мост от тех методов изучения и понимания истории, которые мы привыкли считать последним словом европейской науки, к тем методам и приемам, при помощи которых он сам не то объяснял, не то строил русскую историю. Мы взяли от него сразу и метод, и самые результаты ${ }^{31}$.

Курс лекиий по русской истории Ключевского оказался для Милюкова продуктивным источником, открывшим ему путь в исследовательские пласты. На лекциях и в дружеском общении артикулировались резонансные темы современной российской действительности, устанавливались параллели с историческим прошлым. Такая позиция - искать в прошлом настоящее - нашла отражение в Очерках Милюкова. Критикуя монистический взгляд на историю и обосновывая необходимость применения многофакторного анализа при изучении культуры и общества, он постарался выстроить собственный социокультурный комплекс на поливариантной основе. Милюковская версия по сей день иллюстрирует значимость перекрестного изучения политических, экономических, социальных,

30 В. О. Ключевский, Афоризмы и мысли об истории, в: В. О. Ключевский, Сочинения в 9-ти томах, т. 9, Москва 1990, с. 375.

31 П. Н. Милюков, В. О. Ключевский, в: В. О. Ключевский: Характеристики и воспоминания, ред. Н. Умов, Москва 1912, с. 186. 
правовых, психологических, интеллектуальных, идейных, религиозных и этических элементов исторически развивающихся самобытных культур. Милюков признает значимость теории Чаадаева, обнаружившего общую связь идей христианской исторической философии. Но как исследователь, ориентированный на поливариантное видение истории и культуры, Милюков, конечно, отмечает односторонность его подхода - не только католичество, но и православная религиозная идея в таком контексте может получить всемирно-историческое значение.

Оставаясь верной своей старой системе, Чаадаев не мог сделать сам этого последнего вывода, так как он не мог согласиться приписать всем историческим процессам одинаковую закономерность. То и другое сделали уже представители следующего поколения ${ }^{32}$.

Современные исследователи резонно констатируют идею необходимого альянса философии и политики «во имя создания прорыва в иные регистры возможного существования человеческого сообщества» ${ }^{33}$. Пример Милюкова в какой-то мере подтверждает идею того, как ученый в его специфическом режиме постижения истины может проникнуться желанием реализовать свои либеральные настроения, для чего и обращается к политике как коллективному средству осуществления демократических преобразований.

Сам Милюков признавался, что политика нуждается в законах социальной науки, без знания которых трудно выработать правильные политические решения. «Познающий и действующий субъект стоят так близко друг к другу, так часто совмещаются в одном лице, что смешение научной и практической точки зрения становится самым обыкновенным случаем», - пишет он в Очерках ${ }^{34}$. В качестве

32 П. Н. Милюков, Главные течения русской исторической мысли, т. 1, op. cit., с. 395.

33 Б. Л. Губман, А. Бадью: философия и политика, «Философские науки» (2015) 9, c. 46 . 
эксперта историк может претендовать на право устанавливать факты, используемые потом практическим политиком.

Худо ли, хорошо ли сложились явления нашего прошлого, судить об этом не дело историка, но он обязан указать, как именно они сложились, и практический политик не имеет права игнорировать его указаний. Для успешного хода спора хорошо уже будет то, если стороны согласятся признавать известные факты. Спор от этого, конечно, не прекратится, но, может быть, точнее определятся границы, в которых можно спорить, и некоторые решения сразу будут устранены, как не признающие этих границ ${ }^{35}$.

\section{Резюме}

Обращение к философии истории может стимулировать выбор жизненной позиции автора, рефлексирующего по поводу прошлого и настоящего своей страны. Чаадаев демонстрирует пример того, как политик может извлекать уроки истории. По жизненной ситуации располагавший большими связями и удачно начавший на виду у всего двора свою служебную карьеру, он стоял близко к тем сферам, в которых делается политика и где ощущаются ее непосредственные результаты. Вопрос о том, почему он оставил сферу публичной политики и ушел в отставку, имеет много ответов, диапазон которых довольно широк: от причин, вызванных светскими сплетнями и жизненным кризисом, - до условий, связанных с субъективными переживаниями автора Философических писем за свое «некультурное отечество», со стремлением служить ему, с решимостью писать для поучения своих сограждан. На этом фоне, пересекающаяся позиция Гершензона и Милюкова - оценивать Чаадаева как гражданина - выглядит наиболее убедительной. Обостренное чувство гражданственности и, вполне возможно, здоровое честолюбие, заставили Чаадаева - потенциального от рождения политика - отказаться от светских привилегий и погрузиться в сферу

35 П. Н. Милюков, Очерки по истории русской культуры, ор. сit., с. 726. 
историко-философской рефлексии. Жизнь Милюкова показывает обратное явление: научные идеи, воспринятые им, повлияли на личные мировоззренческие установки. Поливариантное видение исторического развития способствовало формированию либеральных воззрений Милюкова. В силу турбулентности социальных и политических событий в России рубежа XIX-XX веков Милюков оказался не просто кабинетным ученым, но и политиком. Признание базовых либеральных ценностей привело его в ряды партии конституционных демократов.

Жизненный путь и творчество Чаадаева и Милюкова демонстрируют возможность пересечения и одновременно не пересечения грани между философией и политикой. Чаадаев ушел из сферы политики (отставка) и вернулся в публичную сферу в специфическом облике идейного эксперта (английский клуб, приемы в доме на Басманной). Милюков «ушел» из науки в политику (партия конституционных демократов, министерство иностранных дел), но при этом продолжал рефлексировать над проблемами истории и культуры под впечатлением бурных трансформаций действительности (годы ссылки, эмиграция). Судьба обоих мыслителей дает основание признать возможность альянса философии и политики во имя поиска национальной идентичности и осознания необходимости новых регистров межкультурного согласия.

\section{Библиография}

Бердяев Н. А., Филособская истина и интеллигентская правда, в: Вехи. Из глубины, ред. А. А. Яковлев, Москва 2010, с. 48-67.

Гершензон М. О., П. Я. Чаадаев. Жизнъ и мыиление, Санкт-Петербург 1908. Губман Б. Л., А. Бадью: философия и политика, «Философские науки» (2015) 9, c. $34-48$.

Гуревич П. С., Чему учит история?, «Вестник аналитики» 56 (2014) 2, с. 100-121. Кизеветтер А. А., Московский университет и его традиции, «Русская мысль» 26 (1905) 1, c. 1-13. 
Кирпичников А. И., П. Я. Чаадаев, «Русская мысль» 17 (1896) 4, с. 142-155.

Ключевский В. О., Афоризмы и мысли об истории, в: тот же, Сочинения в 9-ти томах, т. 9, Москва 1990, с. 363-446.

Кондуров Р. В., Историософия П. Я. Чаадаева как проблема русской культуры: историко-философский аспект. Автореферат диссертации, Краснодар 2003.

Культура и политика: Сборник научных трудов, ред. Б. Л. Губман, Э. Матыня, Тверь 2004.

Милюков П. Н., Воспоминания, Москва 1991.

Милюков П. Н., Главные течения русской исторической мысли, т. 1, Москва 1898.

Милюков П. Н., В. О. Ключевский, в: В. О. Ключевский: Характеристики и воспоминания, ред. Н. Умов, Москва 1912, с. 183-217.

Милюков П. Н., Интеллигенция и историческая традиция, в: Анти-Вехи. Интеллигениия в России. «Вехи» как знамение времени, ред. В. В. Сапов, Москва 2007, с. 91-176.

Милюков П. Н., Очерки по истории русской культуры, т. 1, Москва 2010.

Михайлова Е. Е., Особенности философии истории русского позитивизма, «Вече» 27 (2015) 2, с. 48-57.

Чаадаев П. Я., Философические письма, в: тот же, Полное собрание сочинений и избранные письма, т. 1, Москва 1991, с. 320-440. 